\title{
РАЗВИТАК ДИЈАЛЕКТОЛОГИЈЕ НА СРПСКОХРВАТСКОМ ЈЕЗИЧКОМ ПОДРУЧЈУ У ХІХ ВЕКУ
}

Дијалектологија као засебна научна дисциплина није тако стара. Тек се у XVIII веку лингвисти обраћају народним говорима да би у њима нашли потврде за поједине своје поставке и закључке, да бисмо у XIX веку добили посебну грану лингвистике која је у средиште својих испитивања ставила народне говоре. За развој дијалектологије, и не само дијалектологије, велике заслуге припадају младограматичарима. Још је A. Meje (A. Meillet) рекао да нема ни историје језика, ни лингвистике без дијалектологије и лингвистичке географије. Данашња наука о језику тешко би се и могла замислити без података што нам их нуди дијалектологија, која нам помаже не само да упознамо структуру живог народног говора него и да пратимо развојне путеве појединих фонетско-морфолошких промена. Дијалекти за лингвисте, по речима Севера Попа, имају исту вредност као биљке за ботаничаре (La Dialectologie... Louvaine, стр. IX). Истина, било је времена када се није тако мислило о народној ризници језичких података, било је времена када су народни говори сматрани нечим ружним, погрдним, нечим што заслужује да се уништи, јер је продукт незнања и каприца. Наравно, нама је данас потпуно јасно да су таква мишљења, и такве жеље, заблуда једног одређеног периода развитка научне мисли, као и то да никакви декрети нису у стању да униште народне говоре и да свим члановима једне језичке заједнице наметну потпуно идентичан језички израз. И управо због таквих својих особина народни говори су непресушна ризница из које историја језика користи оно што јој је потребно. Писана реч, која нам омогућује да пратимо језичку еволуцију од првих писаних споменика на овамо, ма колико била драгоцена и без које је незамислив рад на историјској граматици једног језика, има и својих недостатака. Не само што нам она не нуди ништа о физиолошким и прозодијским карактеристикама фонема и морфема и говорних целина, него је често оп- 
терећена канцеларијским шаблонима из којих тешко продиру особине живе речи времена и места где је та реч стављена на писаћи материјал. Дијалектологија ту има вишеструку предност. Она нам нуди материјал из живог говора. Тај материјал, што зависи од тога ко га бележи, даје нам вишеструке податке о фонетским вредностима појединих фонема који нам, опет, омогућавају да доносимо судове о појединим гласовним променама извршеним знатно раније у језику. Без дијалектолошких података нама би данас биле мање јасне и многе појаве у прозодији не само нашега језика него и словенских језика у целини. Дијалектолошки радови су управо потврдили нека теоретска открића, нпр. постојање и вредности метатонијског акута и сл. Дијалектолошки подаци, ако су прошли кроз руке стручњака, имају већу вредност од онога што нам нуди писана реч. Писана реч може бити и плод пишчева језикотворства, општекомуникативна реч никада није инвентар вокабулара само појединаца. Све оно што је продукт „каприца”, одумире заједно са својим креаторима. У писаној речи често није тако.

Ово је све било потербно рећи да се види оправданост Вуковог поступка при обраћању народном говору за све оно што га је интересовало из области језика. И управо због тога се може рећи да је Вук Стефановић Караџић родоначелник и ове наше научне дисциплине. Истина, и пре Вука, и знатно пре Вука, ми налазимо у делима наших писаца, лексикографа и граматичара подоста дијалектолошке грађе, али је чињеница да до Вука ми немамо систематскијег прикупљања дијалектолошког материјала и његовог публиковања. Мада Вук није објавио, нити написао, било какву расправу из ове језичке дисциплине, ми и данас често полазимо од материјала који нам је он оставио.

Ако и пренебрегнемо чињеницу да и у првим писаним документима на нашем језику има и дијалектолошког материјала који нас обавештава, приближно тачно, и о времену и о месту настанка тог писаног документа, или бар пореклу његовог писара, не можемо а да не укажемо на корисност података које нам о појединим народним говорима пружа наш познати комедиограф из Дубровника, Марин Држић. Поред говорних особина његових суграђана, ту налазимо и особина из говора дубровачког залеђа: чакавских говора, Херцеговине, Котора, вама је то свакако познато. Познато вам је и то да Држић, како констатује Милан Решетар, није желео да да „некакву дијалектолошку антологију, него је само ишао за тим да, по примјеру талијанских комедиографа својега времена, појача комички ефект неких шаљивих лица износећи њихове језичне особине које су за дубровачке грађане биле у свагдашњем говору необичне, па зато и смијешне". И код других писаца тога времена има дијалекатског 
материјала, мада се код њих осећа и тежња за стварањем књижевног израза и опредељење за један говорни тип.

Наши старији лексикографи такође уочавају дијалектолошке разлике на нашем језичком тлу и, што није неважно, многи од њих се опредељују за једно наречје, један говорни тип, како би се, по угледу на неке друге језике Европе, и код нас усталио јединствен писани израз. Те њихове тежње лепо је исказао лексикограф Јаков Микаља повлачећи паралелу између језика, који је он изабрао за свој речник, и његовог матерњег језика - италијанског. У италијанском језику, пише Микаља... има врло велике разноликости у говору - али када се пише настоји се да то буде на тосканском или римском наречју и свак се труди да тим наречјем пише књиге - Зато и он, као и неки други лексикографи тога времена, предлаже да се усвоји босански говорни тип за нашу писану реч (в. о томе В. Јагић: Изабрани краћи списи, Загреб 1948, 49-50).

Све су ово, да поновимо, били помени о нашим народним говорима. Битнијег улажења у ту проблематику немамо све до Вука. Вук је и ту почео да крчи нову стазу. Он је дао и прву целовитију слику наших дијалеката и њихову поделу на три основна дијалекта која се одржала све до наших дана.

Истина, Вуково гледање на наше дијалекте мењало се онако и онолико колико је он успевао да се лично обавести о скупу њихових релевантних особина. У песмарици из 1814. спомињу се само херцеговачко и сремско наречје и даје се њихова основна диференцијална особина, рефлекси јата, као и њихова територијална распрострањеност. Наравно, све према тадашњем његовом познавању ове проблематике. У Писменици, из исте године, спомињу се херцеговачко, сремско и славонско - главна разлика је у неједнаким рефлексима јата. Дакле, ту је још реч само о говорима штокавског дијалекта. Ни у Рјечнику из 1818. не иде се даље од ове поделе. Ту је: херцеговачко, ресавско и сремско, као и у годину дана раније објављеној рецензији Видаковићевог „љубомира у Елисиуму". Славонско наречје Вук ту не спомиње. Окосница наведених наречја је замена јата: херцеговачко има ије, је; сремско е, али са извесним бројем икавизама; ресавско је доследно екавско, а зна и за неке фонетске и морфолошке особине које не налазимо у друга два наречја. Све су то подаци у које се није могло сумњати. Њих је Вук лично забележио, или их је добио од сигурног информатора (в. Љ. Стојановић: Живот и рад Вука Стеф. Караџића, Београд 1924, 92. и даље). И у доцнијим Вуковим радовима, све до Писма о језику, из 1845, Вук се држи штокавског дијалекта и даје податке о његовим говорима и наречјима, а 1839, у „Одговору на ситнице језикословне” Ј. Хаџића, Вук даје новије називе наречјима што- 
кавског дијалекта: источно, са $e$ м. јата; западюе, са $u$ м. јата и јужно, где се јат изговара „од више руку” - uje, je, e, u (Скупљени грам. и пол. списи, III, 36-37). Ову поделу штокавског дијалекта, која регионалне називе замењује општегеографским, први пут налазимо код Ј. Грима и остаће у нашој науци све до наших дана. Значајно је да Вук увек сва та наречја даје као потпуно равноправна.

Потпуно је схватљиво што се Вук све до педесетих година прошлога века држао штокавског дијалекта и давао његову поделу. За то, чини ми се, постоје два важна разлога:

1. Он је износио материјал српскога језика (и речник и граматика имају одредбу: српски), а целог живота је сматрао да штокавским дијалектом говоре само Срби. 2. Њему све до педесетих година нису биле познате особине ни чакавског ни кајкавског дијалекта, иако је имао могућности да се упозна са старијим речницима у којима се даје лексичко благо и тих дијалеката (у писму Копитару од 14. јануара 1816, из манастира Шишатовца, Вук моли Копитара да му пошаље „све шокачке рјечнике, као н.п. Штулиа, Јамбрешића, Делабелу и Белостенца" (Вукова преписка, I 153), што је овај одмах и учинио (оп. цит. 161). Из тих речника Вук је могао да добије слику и о остала два дијалекта нашега језика, али се он у то није упуштао. Прво зато што те дијалекте није сматрао српским, друго зато што материјал који су му нудили ови речници није у свему одговарао његовом схватању и његовом принципу одбира лексичке грађе. Истина, он ће и у радовима пре педесетих година спомињати и чакавце и кајкавце. У Рјечнику из 1818. Вук даје одредницу кекаваи (кајкаваи) са објашњењем: Der Kroate, der kaj (statt uma) spricht. Дакле, ту је за њега кајкавац Хрват, а не Словенац, као што је мислио Копитар. У Рјечнику има и нешто чакавске и кајкавске лексике (в. Белић: Вукова борба, 168), а и сам се 1836. и 1838. упознао са особинама тих дијалеката. Ипак, све до почетка пете деценије п.в. он не даје више грађе о чакавским и кајкавским говорима. У његовом чланку „Критика о језику”, објављеном 1843. читамо да су чакавци они „који мјесто што или шта кажу ча” и који имају сачувано $\pi$ на крају слога: причал, рекал.

Када је Вук увидео да би било добро да његова реформа језика и правописа обухвати цело српскохрватско језичко подручје, он је морао да донекле мења своје схватање о књижевном језику, мада није променио и схватање повезаности језика и националне припадности оних који говоре тим језиком. А управо му је то и сметало да се ослободи знатно раније прихваћеног мишљења, које није могло да издржи критику времена, по коме су штокавци Срби, Хрвати чакавци, а кајкавци су или Словенци или некакав прелаз између српског и словеначког језика, и 
да усвоји, иначе разложне и аргументоване доказе које је у вези са овом проблематиком изнео Б. Шулек. Што је то било тако, не треба кривити само Вука. То је било схватање ондашњих водећих слависта: Копитара и Миклошића (в. код Јагића: Спомени мојега живота, Београд 1930, I, 351). И управо због тога он почетком педесетих година прикупља грађу и о чакавском дијалекту. Не треба заборавити да је Копитар умро 1844, и да је Вук имао јаку жељу да нађе заједнички језик са представницима илирског покрета - а то је био императив времена. Све је то, привидно, имало утицаја и на Вуково интересовање за говоре ван штокавских граница.

У Писмима о српском правопису и језику из 1845 , поред изношења мишљења о наречјима штокавског дијалекта и разлога који су утицали на његово опредељење за ијекавски изговор, Вук ту наводи и чакавце и кајкавце. За прве каже да „говоре уопћено језиком Далматинскијех примораца и острвљана”; а Крањци „заносе много на прави Хрватски или Крањски језик" (Скуп. грам. списи, III 182). Годину дана касније, у „Критици о језику” даје се шири поглед на чакавски дијалекат. Ево како то Вук износи:

- Чакавце сам ја, пише Вук, спомињао до сад њеколико пута, а сад ћу да кажем о њима више.

Чакавци су по свој прилици остаци Порфирогенитовијех Хрвата. Њихова је данас права земља или домовина Далматинска острва и гдјекоја приморска мјеста... осим тога има их по Хрватској, по западној Маџарској и по Аустрији готово до Беча. Језик се њихов мало разликује од правога Српскога, али је опет њему ближи него и какоме другоме Словенском наречју (Скупљени грам. списи, III, 195). Од чакавских особина наводе се: икавизам, неизменено л на крају слога, ј према шток. ђ у: меја, преја, стабилност фонеме х, ген. пл. без -а, или са -их: голубих, прстених; лок. пл. на -их и -ах; у 3. л. пл. през. -ду: пишеду, молиду; чува се супин, контраховани заменички облици: ки, ке, ма (који, које, моја); сугл. скупина шћ према штокавској шт у: пришћ, огюишће; сонант м у финалној позицији губи билабијални карактер и прелази у алвеоларни сонант $\mathcal{H}$; имају и заменицу ча „почему их и Чакавцима називају”. Овај списак чакавских особина Вук ће допунити у чланку „Срби сви и свуда” који је објављен 1849. Ту је сада на првом месту односно-упитна заменица ча, с напоменом да има и цза, поред неких од раније наведених чакавских изоглоса сада се дају и појава $а$ м е у: јазик, jam, nрuјат, јамат, затим ре према шток. ра у рести и вребаи; ту је и греб, чакавци имају и лексичких специфичности: криж, крух, и сл. (op. cit. 291-292). Уз све ово долази и један целовитији поглед на наше језичко подручје. - Из свега овога што је овдје казано, пише Вук, види се да се јужни Славени сви осим Бугара 
по језику дијеле на троје: први су Срби, који говоре што или шта (и по чему се према Чакавцима и Кекавцима могу назвати Штокавии) и на крају слова имају о мјесто л; други су Хрвати, који мјесто што или ита говоре ча (по чему се зову и Чакавци) и на крају слогова не промјењују л на o, а у осталоме се врло мало разликују од Срба; трећи су Словении, или као што их ми зовемо Крағии, који мјесто што говоре кај (по чему их наши и Кекавиима зову), који се и од Срба и од Хрвата по језику много више разликују него Срби и Хрвати између себе, али су опет ғыма ближи него и једноме другоме Славенском народу" (ор. cit. 295-296; делимично је моје подвлачење, А.П.).

Нама је данас јасно да Вукове представе о члановима јужнословенске заједнице нису биле потпуне, јасно нам је да и његово везивање националне припадности за дијалекатску припадност није могло да остане у науци, јасно нам је и то да кајкавски дијалекат чини саставни део српскохрватске језичке територије, а да је словеначки језик посебни члан јужнослов. језичке заједнице. Али, да поновимо, Вук је ту ишао за мишљењем признатих ауторитета у славистици, иако није робовао њиховим схватањима, или не у свим појединостима. У одговору на Шулеков чланак „Срби и Хрвати” који је објавио под истим насловом 1861, дакле, три године пред смрт, Вук каже да се Хрвати „по правди могу назвати 1) Сви Чакавци; 2) Кекавци у Краљевини Хрватској који су се на то име већ навикли" (Скупљени грам. списи, III, 467). Тиме је Вук дао и коначни одговор на питање дијалекатске разуђености наше језичке области - у границама српскохрватског језика сада су се нашли сви наши дијалекти и дате су многе њихове битне особине (Указујем овде на мишљење које је проф. Станислав Хафнер изнео на III међународном скупу слависта у Београду. По Хафнеру: „са данашње тачке гледишта посматрано (Вуков) профани став према средњовековној традицији и деконфесионализирано језичко замишљање света стварали су... услове за реформу језика, који су били потребни да би (његово) деловање постало познато преко граница православног Српства, иначе би сигурно питање језика остало српско, а самим тим и православно питање”. Ми уз то додајемо да без оваквог Вуковог става не би дошло ни до Бечког договора 1850). Али тим није дат и за науку прихватљив одговор на питање да ли стварно постоји апсолутно поклапање између националних и дијалекатских припадности, да ли уз то кајкавски припада српскохрватском језику или је то дијалекат словеначког језика. Та питања решавала је наша језичка наука у другој половини прошлог века. А да би се добио одговор на та питања, требало је кренути у историју, требало је прегледати старе писане споменике и видети шта нам они о томе нуде. Тога посла латиће се Даничић, 
Јагић и др. Дакле, сада се напушта дијалекатски материјал и иде се за писаном речју да би се добио одговор који је и те како важан, и за дијалектологију. Јагић је одмах на старту негирао учење по коме дијалекатска припадност повлачи за собом и националну припадност, тј. негирао је учење Миклошића и Вука, али он иде у једну другу крајност и повезује националност са наречјем: икавци су Хрвати, екавци су Срби, а јекавци су симбол „здружеюа и помирења” и зато тај изговор треба примити као једино књижевни. (Изабрани краћи списи, 34).

Јагић је ту изнео и још једно, за нас овде интересантно, мишљење, а то је да оно „што зову нарјечјем чакавским и штокавским” није права разлика међу народом хрватским и српским. Упирући ово доказивање на језик као најбитнији знак народних разлика или сродности, продужује Јагић, изводио сам... тај посљедак, да оно, што зову чакавштином, сматрам по језикословних захтјевих старијим одсјеком онога другога нарјечја, које долази под именом штокавштине" (изабрани списи, 36), а ту има много научне истине, јер многе данас типично чакавске особине некада су постојале и у говорима штокавског дијалекта (в. Белић: Језичко јединство... Даничићев зборник, стр. 45).

На овим питањима радио је и Даничић. И он је настојао да проникне у суштину разлика између језика Срба и Хрвата. Док је у раду „Разлике између језика српскога и хрватскога”, који је објављен 1857. од регистрованих 107 разлика издвојио 3 као непомирљиве: ђ - j, вршење односно невршење новог јотовања, супституција односно чување сонанта $\pi$ на крају слога, да би и сам доцније увидео да ни $\pi$ ни резултати новог јотовања немају исту доказну моћ као однос ђ и ј у пређа (преја) и сл. На дијахроном плану обе наведене особине биле су познате и свим штокавским говорима. У чланку „Ћ и ђ у историји словенских језика” (Рад I, 1867) Даничић долази до закључка да и штокавско ђ и чакавско $j$ имају заједничку основу у старијем $\hbar$, што ће доцније Јагић свести на $\partial$ '. Тиме Даничић долази до закључка да је језик Срба и Хрвата један и да га треба звати српским или хрватским језиком, односно хрватским или српским језиком (в. Белић: Језичко јединство, 52).

Дакле, шездесетих година прошлога века скинуто је са списка питање односа штокавског и чакавског дијалекта, скинуто је и питање у ком односу стоји језик Срба и Хрвата, ми бисмо данас рекли дошло се до спознаје да је језик којим говоре Срби, Хрвати, Црногории и Муслимани један. Из таквог сазнања уследило је и издавање Рјечника хрватског или српског језика чију је прву књигу и приредио Даничић. Истина, и то је потребно истаћи, Миклошић је био одлучно против таквог назива нашега језика. У његовој упоредној граматици слов. језика о томе читамо: Hier 
möge bemerkt werden, dass mir serbisch und chorvatnsch als zwei Sprachen gelten, und dass ich den Ausdruck језик српски или хрватски für falsch halte" (Ferg. Gram. I, 392). Али, истини за вољу, ни ту Миклошић није имао право. У науци је остало управо оно што је Даничић констатовао.

Пада у очи да овде нема речи о кајкавском дијалекту. Даничић није ни у свој речник уносио грађу из дела насталих на томе дијалекту, а то због тога што је и он сматрао да је кајкавски прелазни дијалекат између српскохрватског и словеначког језика (в. П. Скок, ЈФ XII, 92). Време је тражило да се и тај проблем реши, да се јасно одреди коме припада један дијалект којим говоре они који себе називају Хрватима. У вези са овим почетком 1880, како нам саопштава Јагић, Фрањо Рачки, први председник Југославенске академије знаности и умјетности, наговарао га је да поводом Ваљавчеве расправе „Принос к нагласу у (ново) словенском језику и хрватској кајкавштини" - која је почела излазити у Раду, а у којој се кајкавски убраја у словенштину - сам проучи овај проблем и о томе напише чланак. У одговору на то писмо Рачкога Јагић пише: „Не мислите да бих ја имао вољу дирати у осје гњездо, ја сам у Хрватској своју ролу изиграо нити марим што се у борби тко на ме позива или не позива" и продужује: „У рецензији на Миклошићеву фонологију ја сам уврстио примјере из старије кајкавштине међу словенске” и додаје „ерго и ја се слажем с Ваљевцем” али уз ово и „Разумије се да филологија није политика" (Спомени стр. 351). Да је то питање копкало и Јагића, видимо из његове преписке. Рачки му је после онаквог писма написао да би било корисно „суставно и с филологичкога гледишта расправити питање о хрватској кајкавштини" јер национално осећање оних који говоре тим дијалектом „не риешава питање.” У одговору на ово писмо Рачкога, у писму од 3. марта 1880, како сам саопштава стајало је: „гледе кајкавштине ово: да не волим доказивати, да је кајкавштина својим организмом ближе к словенштини него ли к хрватштини (ја сам се после дубљим разматрањем историјских процеса уверио да то није управо све тако глатко, како се обично мисли по Миклошићевој теорији. Кај = Словенци, ча = Хрвати, што = Срби)” и продужава. „Што су Словенци кајкавци (тј. становници словенске краљевине = Славоние регнум) Хрватима постали, то им служи на част те доказује, да би и они остали кајкавци могли бити поћи истим путем, да их није јача сила њемачка прикључила к себи” и закључује да „народно јединство не виси тек о граматици”, а то се види одатле „што сада Срби и Хрвати пишу једним језиком” иако им тежње нису исте (Спомени... стр. 351-352). Две године касније, у VI књизи Архива, Јагић се враћа на ову мисао и пише. Sprachlich, d.h. wenn die linguistischen Merkmale eines gesprochenen Dialektes allein in die Wagschale 
fielen, würde ich selbst nach dem Dialekte meines Elternhauses, meiner Vaterstadt und der engsten Heimat überhaupt zu den Slovenen zählen, das lässt sich nicht leugnen, ebenso wie man anderseits sagen darf, dass der politicshe Verband und die höheren Ideen der glücklichen und segensreichen neueren Zeit meine Heimat zum untrennbaren Glied eines anderen grösseren Ganzen gemacht haben" (стр. 313-314). Проблем припадности кајкавског дијалекта, као што видимо, није био прост. Ове мисли Јагић ће поновити и пред своју смрт. Наиме, у његовим Споменима, на последњим страницама друге књиге, што значи на страницама које су написане у последњим данима Јагићева живота, читамо да: „етничка свеза и јединство не почива само на граматичним облицима - јер ту - спадају и други фактори који каткада више значе неголи граматика или дијалектологија - и даље - Макар дијалектолог налазио да је говор загребачке околице ближи словенској групи, укупни резултат хисторичког, политичког и културног живота не обазире се на граматичку мудрост те тамошњи народ рачуна исто тако међу праве Хрвате као онај његов део међу Купом и морем, или на отоцима у Далмацији” (стр. 247). Као што видимо, Јагић је овде узимао као мериторне екстралингвистичке моменте, који, без сумње, имају изванредно велику доказну моћ у оваквим проблемима. Лингвистичко осветљавање овога проблема биће извршено тек у нашем веку када се и то питање из наше дијалектологије скида са дневног реда и када се прихвата мишљење по коме је данашњи кајкавски дијалекат саставни део српскохрватске језичке територије, а у прошлости је имао тешње везе са словеначким језиком. Истина, не постоји сагласност о томе када су биле те везе са словеначким. За Ф. Рамовша кајкавски је раније био у домену словеначког језика и имао његов развојни пут, али се касније одвојио од словеначке матице „пошто је њихова земља (мисли се на део кајкавског подручја) дошла под нову политичку власт, хрватско краљевство”, а све ово је условило промену како социјалних тако и лингвистичких услова и због тога се сада кајкавски дијалекат више окреће штокавштини. Дакле, по Рамовшу „Кајкавштина је по својој основи словеначки дијалект, који је под утицајем политичких и културних прилика преузео и још преузима штокавске црте” (CHE, VI, 224). А. Белић је другачијег схватања. По њему, кајкавски дијалекат је дошао у тешње везе са словеначким језиком тек после турских продирања у наше земље а у њему су се развиле „у новије време и особине словеначког језика” (CHE, II, 222). Белић ту истиче и чињеницу да „хрватски кајкавски дијалекат, и ако улази у језично подручје српскохрватског језика, представља, у исто време, и врло драгоцену везу нашега језика са словеначким" (CHE, II, 210). 
Друга половина прошлог века, као што смо видели, имала је на дневном реду, бар што се дијалектологије тиче, више теоретску него практичну страну наших народних говора, и управо због тога ми из тог периода немамо неку већу дијалектолошку студију. Истина, у то време су објављени бројни ситнији прилози из дијалектологије из пера П. Будманија, Брајковића, Миласа, Шурмина, Решетара, Живановића, Кушара, Милчетића, Облака, Строхала, Рожића и др. (в. М. Храсте: Библиографија радова из дијалектологије... ХДЗб и осврт на тај рад проф. Ивића у Зборнику МС за филологију и лингв. II).

Ми данас можемо констатовати да је друга половина XIX века изванредно значајна за нашу дијалектологију. У то време, још за живота Вукова, нека спорна питања су решена. После Вукове смрти, захваљујући напорима управо вуковаца, много се учинило и на расветљавању преосталих спорних питања тако да ће све оно што је тада практично урађено на пољу наше дијалектологије бити припрема за оно што смо добили на почетку овога века када се јављају са својим радовима Решетар, Белић и Ившић чији ће радови овој грани наше науке о језику дати завидно место у славистици. 